\title{
Configuration of the Self-Mythology and Identity of Female Characters in Paul Auster's In the Country of Last Things and The New York Trilogy
}

Mohammad Amin Shirkhani*

Department of English and Cultural Studies, Panjab University, India

Corresponding Author: Mohammad Amin Shirkhani, E-mail: Aminshirkhani0114@gmail.com

\section{ARTICLE INFO}

Article history

Received: May 16, 2017

Accepted: July 25, 2017

Published: December 01, 2017

Volume: 6 Issue: 7

Special Issue on Language \& Literature Advance access: September 2017

Conflicts of interest: None

Funding: None

\begin{abstract}
The works of American novelist Paul Auster (1947-) are uniquely concerned with the mythology of self, metanarrative and the role gender plays in these transactions. In his earliest works, The New York Trilogy (1985-1986) and In the Country of Last Things (1987), Auster uses genre conventions and styles (for the former, detective novels; for the latter, dystopian fiction) to interrogate these preconceptions of self-mythology and the role of gender within these genres, subverting tropes and traits of these works to comment upon them. In the following, we investigate these works in depth along these themes, conducting a close textual analysis from the framework of Freudian and Lacanian theories of psychoanalysis and poststructuralism. By investigating the roles of women in The New York Trilogy and In the Country of Last Things, we hope to illuminate Auster's uniquely postmodernist, deconstructive approach to the psychological imperatives women are socialized into within American society, and how they are informed by narrative and mythology. The role of women, from the absent trophies of The New York Trilogy to the central voice of sanity of Anna in In the Country of Last Things, posits women as a societal superego whose goal it is to keep the destructive, nihilistic $i d$-like impulses of men in check.
\end{abstract}

Key words: Paul Auster, Self-mythology, Psychoanalysis, Post-structuralism, Gender Studies

\section{INTRODUCTION}

Identity, gender and mythology are essential components to the fabric of human society as we know it. Our society is made up of stories and narratives, those that are told to us and those that we craft for ourselves. The way in which we investigate those narratives can often lead us to greater insights into our individual and collective psyches, bringing us closer to answers regarding the essential nature of mankind and our mythology. The mythology of self, the process by which we determine and craft our own individual importance to the community at large, is increasingly important to this investigation. Often, this self-mythology is negotiated or mitigated by one's gender, and the social prescriptions and limitations on what people of certain genders can do.

The works of American novelist Paul Auster (1947-) are uniquely concerned with the mythology of self, metanarrative and the role gender plays in these transactions. In his earliest works, The New York Trilogy (1985-1986) and In the Country of Last Things (1987), Auster uses genre conventions and styles (for the former, detective novels; for the latter, dystopian fiction) to interrogate these preconceptions of self-mythology and the role of gender within these genres, subverting tropes and traits of these works to comment upon them. In the following, we investigate these works in depth along these themes, conducting a close textual analysis from the framework of Freudian and Lacanian theories of psychoanalysis and poststructuralism. By investigating the roles of women in The New York Trilogy and In the Country of Last Things, we hope to illuminate Auster's uniquely postmodernist, deconstructive approach to the psychological imperatives women are socialized into within American society, and how they are informed by narrative and mythology.

\section{REVIEW OF LITERATURE}

\section{Psychoanalysis}

The practice of psychoanalysis was developed and popularized by Sigmund Freud (1919), in which one's dreams, personalities, and desires were analyzed in order to best determine the unconscious wants of the mind. Central concepts related to Freud's (1923) approach to psychoanalysis involve the id, ego and superego - a tripartite structure to the human psyche that serves different purposes. The id is in charge of our sexual and aggressive drives, as well as our primitive instincts; the superego acts as the moral conscience for an individual; and the ego mediates between these two polar opposites to create a nuanced, realistic personality. 
Freud (1919) also discusses the idea of the Uncanny, or that which is real yet feels distinctly unreal. Freud (1919) referred to the uncanny as 'das unheimlich,' categorizing it as uncomfortable and unfamiliar, yet completely concealed from our knowledge. In fiction, the uncanny is typically utilized to depict something that is decidedly out of its own environment. With this concept of the Uncanny, as well as the $i d$, ego and superego, a Freudian psychoanalysis can be achieved on fictional works by evaluating these aspects of the work's characters.

In addition to the Freudian perspective, Jacques Lacan (2007) posited a theory of the human psyche that framed itself within a spectrum between need, demand and desire. Lacan posits that human beings demand things of others, based on their needs and desires, and this is what drives our attitudes and behaviors, however conscious or subconscious. According to Lacan, we are mostly driven by our desire to be recognized by an 'Other,' and/or to desire what the Other also desires or lacks (Lacan, 2007). Desire is what drives our need to be recognized and validated by others: "Desire is neither the appetite for satisfaction nor the demand for love, but the difference that results from the subtraction of the first from the second, the very phenomenon of their splitting (Spaltung)" (Lacan 2007, p. 690-692). In essence, desire happens when demands exceed our needs; we may meet our needs in some way, but what we demand beyond that becomes our desire.

\section{Self-mythology}

The mythology of self is a philosophical and psychological concept dating back before the ancient Greeks, and refers to the ways in which we develop our own personal stories to fulfill our own sense of significance (in much the same way as cultural myths establish the importance of societal traditions and collective knowledge) (Krippner, 1988). In fiction and storytelling, the personal myth has existed as far back as The Epic of Gilgamesh, and Greek mythology like the works of Plato ("The Apology of Socrates"), Sophocles (Antigone), and Euripides (Medea) (Krippner, 1988). However, the modern understanding of the term "private mythology" was coined by Carl Einstein in 1926, in his estimation of painter Paul Klee's work and how it related to his audience. The term has also been found in the works of Carl Jung, as he begins his autobiography Memories, Dreams, Reflection with, "Thus it is that I have now undertaken, in my eighty-third year, to tell my personal myth" (Jung 1963, p. 3).

Self-mythology is a fundamental component of psychology and psychoanalysis, as it relates directly with the symbols and values individuals use to form and craft their sense of identity. The mythology of self can take the form of stories from our youth that define our personality traits - for instance, a dangerous fall when you are young could establish the 'mythology' of your fear of heights, or a bad breakup can establish your relationship issues depending on the cause. These, according to Krippner (1988), can heavily inform our personality and the impact we make on our community: "We use our stories as personal myths" (Krippner 2009, p. 7).
In the context of Auster, scholars have explored the ontological nature of his characters as vehicles for exploration of the self and personal mythology. Dimovitz (2006) explores the ways in which language and identity are explored in Auster's New York Trilogy, utilizing postmodernist thoughts and strategies to cultivate a metaphysical perspective on his characters that eschews traditional detective novel dogma. For Auster's characters, argues Dimovitz (2006), their construction within the novel demands a level of self-reflection and self-consciousness that inherently disrupts the typical understanding of consciousness and identity, creating a world that thrives more on chance than a true comprehension of self.

Loebberman (2012) envisions Auster's City of Glass and In the Country of Last Things as investigations of the homeless and the pedestrian. Positing a theory that there is a strong link between artists and the homeless in Auster's work, Loebberman (2012) makes a case for the intransigence of Auster's characters (e.g. Anna in Country) as something to admire and respect - an aimlessness that prevents them from being tied down to orthodox systems of ownership and possession, such that they can find a greater truth. In mapping and charting the paths of these otherwise aimless figures, Loebberman asserts that the stereotypes of the homeless are thus elevated into a type of personal mythology of freedom and transcendence from typical cultural norms.

Auster's work also relates deeply to the specificity of the American myth, and how its citizens fit into it. Gonzalez (2011) examines Auster's later works in the context of his former ones, citing his oeuvre as an intriguing example of the ways in which the American story has informed the attitude of its citizens. Whether through genre fare like the detective story in The New York Trilogy (an example of the post-war interest in dark, cynical explorations of the human condition in growing urban landscapes) or the kind of Cold-War dystopian nihilism seen in In the Country of Last Things, Gonzalez (2011) asserts Auster's deep connection to these myths throughout his works, deconstructing them to demonstrate the innate distrust and cynicism that occurs in the American personality as a result of its myths.

\section{Poststructuralism and Metanarrative}

The existing scholarship on Paul Auster's work frequently invites discussion of postmodernism, deconstruction, and the unconventional narrative style he utilizes in his works. One of Auster's most prominently explored attributes is his use of metanarrative and poststructuralist techniques to subvert expectations and conventions of the genres in which he writes. Lavender (1993) writes about City of Glass as a novel of 'critical engagement,' in which the book acts as a detective story that mirrors the act of literary creation - novel writing as the solving of a mystery. Here, Auster's approach is explored as a philosophically potent investigation of the ways narrative convention can be subverted and explored to illuminate truths about the creative mind and fiction in general.

Alford (1995) discusses these same ideas of poststructuralist thought further, this time in the context of physical 
space within The New York Trilogy. In investigating issues of identity and self, Alford shows the ways in which Auster anthropomorphizes these ideas through the vagueness and impossibility of space within his works. The novels, argues Alford (1995), occupy three different spaces - pedestrian spaces, mapped spaces, and utopian spaces - creating a unique relationship between signification, space, and the self. The characters that occupy these spaces, then, understand their own selfhood through their relationships to the signs and symbols of these spaces.

Time is also used in a deconstructive manner in the works of Paul Auster, as Merlob (2007) points out in her discussion of the temporality of Auster's In the Country of Last Things. Merlob (2007) argues that Auster debunks the concept of time as a unifying and ordering principle of a fictional work's narrative, furthering Alford's (1995) argument of space as the unifying principle of the text. Just as with the spaces in The New York Trilogy, Country also features a number of different spaces that relate uneasily to each other, and cultivate an uncertain sense of space that further muddles one's sense of self.

Han (2014), in examining the works of Auster and Charles Brockden Brown, elucidates upon the ways in which trauma and strife can create a shared cultural mythology, which Auster comments upon in his works. Analyzing Auster's New York Trilogy, Han discusses the effect of displacement upon perspective in Auster's novels, tying this idea of the great American mythology to Auster's methods of deconstruction. For instance, Han (2014) points out the distanced first-person perspective of City of Glass, which occasionally lapses into third-person perspective to further complicate identity and how it relates to perspective.

Little (1997), in his examination of City of Glass and the rest of the New York Trilogy, focuses on the philosophical concept of 'nothing' and how it relates most acutely to the metatextual and metafictional nature of Auster's work. Specifically, Little (1997) argues that the minimalism and abstraction with which Auster writes City of Glass contributes heavily to the openness and malleability of artistic interpretation as it relates to intent. This further asserts Auster's poststructuralist bona fides, as the facilitation of multiple readings and abstraction in one's work constitutes the ideals of postmodernist thinking.

\section{RESEARCH METHODS}

For the purposes of this paper, I conducted a close textual analysis of the three books in The New York Trilogy - City of Glass, Ghosts, and The Locked Room - and his 1987 novel In the Country of Last Things. The primary focus of this analysis was to perform close readings of the female characters of each work, examining the ways in which their behavior, motivations, and the way Auster wrote them fit within the framework of Lacanian and Freudian psychoanalysis (the $i d$, ego, superego; Lacanian notions of desire). Elements of poststructuralism and postmodernism were also used to investigate how these characters were utilized to facilitate Auster's commentary upon genre and narrative fiction itself.

\section{RESULTS}

\section{City of Glass}

Paul Auster's New York Trilogy (1986-1987) consists of three novels, City of Glass (1986), Ghosts (1986) and The Locked Room (1987), each of which offer their own individual stories but are tangentially connected by theme, plot and some recurring characters. While each of these novels features few female characters, their limited presence (and their absence) speaks to Auster's attitude toward the American myth and its treatment of women.

City of Glass, in classic Auster style, follows a detective novelist named Quinn, who is mistaken for a real detective (ironically named Paul Auster) and sent on a mission from a strange phone call. The most prominent female figure in the novel is, intriguingly enough, missing from the novel's narrative: Quinn's wife, who (along with his son) died under mysterious circumstances before the events of the novel (Auster 1986, p. 17). Quinn, as befits the prototypical detective novel protagonist, carries that pain with him throughout the book, using his wife's memory as yet another symbol of his grief and the emptiness of his life: "He had nothing, he knew nothing, he knew that he knew nothing" (Auster 1986, p. 159). From a Lacanian perspective, Quinn carries the desire for a normal, everyday life that comes with having a wife and child; his wife's absence in that respect is what drives his own desires.

Apart from Quinn's wife, Virginia Stillman takes center stage as the most high-profile female character in City of Glass. Auster quickly frames Virginia as the femme fatale of these types of detective stories, emphasizing her sexuality and physical beauty as primary traits: "hips a touch wide, or else voluptuous, depending on your point of view... she wore a black dress and very red lipstick" (Auster 1986, p. 13). In a Lacanian sense, Virginia's desire is fueled largely by her genre role as the femme fatale; she dresses seductively for Quinn in order to entice him into compliantly searching for her husband. Beyond their initial meeting, however, Virginia is increasingly abstracted in Quinn's world as a potential replacement for his wife: a recurring motif in the novel is his increasing inability to reach her on the phone: "For the twentieth time he tried to reach Virginia Stillman, and for the twentieth time the same thing happened" (Auster 1986, p. 103). Much like Quinn, Virginia's husband Peter Stillman, abstracts her sexually, dehumanizing her by claiming to not call her by her real name: "Her name is Virginia. That is not her real name. But that makes no difference. To me" (Auster 1986, p. 21). In all of these aspects, Virginia is a very passive character in the Lacanian sense; she does not desire, but is desired - by Quinn, by Peter, by the reader, etc.

\section{Ghosts}

Yet another deconstruction of the classic detective story, Auster further abstracts the genre in Ghosts, the second part of the New York Trilogy. Here, characters are further abstracted and minimized by refusing to give them human names; the plot revolves chiefly around a detective named 'Blue' being hired by a character named 'White' to follow a 
character named 'Black.' Much like the other stories in the trilogy, women are scarcely found; the most active female element in the film is Blue's recollections of "the future Mrs. Blue," who is not featured in the story proper (Auster 1986, p. 136). Much like Virginia in City of Glass, these female figures act as an object of desire and normalization for the grizzled, male protagonists; with femininity comes the impression of sensitivity and nurturing that these hardened gumshoes desperately cling to for normalcy. For Blue, notions of masculine norms of strength and emotional distance keep her away from him:

"He thinks about calling her up on the phone for a chat, hesitates, and then decides against it. He doesn't want to seem weak. If she knew how much he needed her, he would begin to lose his advantage, and that wouldn't be good. The man must always be the stronger one" (Auster 1986, p. 136).

Blue's visions and imaginings of Mrs. Blue act as yet another instance in Auster's postmodern investigation of personal mythology; just as he play-acts his interactions with her in his mind, he concocts a myth of a mutually loving relationship in which he maintains the power in their dynamic. This lends him a feeling of control that is otherwise absent from his detective work, in which "[he] has learned a thousand facts, but the only thing they have taught him is that he knows nothing" (Auster 1986, p. 59).

\section{The Locked Room}

The New York Trilogy concludes with The Locked Room, which is distinct from the previous two entries in its comparative dedication to realism. Here, the story follows yet another detective, Fanshawe, whose circumstances remove him from his woman (his wife, Sophie, left him while six months pregnant with their child) and force him to live a life with the specter of a woman on his mind. However, Sophie remains a presence in both their lives, like Quinn's dead wife and the absent Mrs. Blue of Ghosts, acting as erstwhile inspiration and a reminder of Fanshawe (and the narrator's) romantic failings.

Sophie is chiefly seen in the beginning of The Locked Room, and is presented, like many of Auster's women, as the average caring wife and mother whose husband's moral and character failings were, in turn, failing them. Her Lacanian desires can be defined as the same as the narrator's; to have a husband and a home to rely upon. Her first (and only) major action of the novel comes when she writes a letter to the narrator asking about Fanshawe's disappearance; here, Sophie's desires and needs are not being met, whether sexually, financially, or emotionally, and so she calls on the narrator.

The narrator visits Sophie's home to see her baby, and is immediately drawn to her beauty: "Fanshawe had been lucky. The woman was beautiful, with dark, intelligent eyes, almost fierce in their steadiness" (Auster 1987, p. 197). One of the narrator's first conclusions is that "No man would have left this woman of his own free will" - an implication that life with Sophie and her young child in their modest apartment represented the kind of American ideal that no one would sensibly choose not to maintain (p 197). To that end, the narrator chooses to pursue Sophie for his own piece of the American dream of family; like Fanshawe's detective writing, Sophie is yet another part of Fanshawe's life that the narrator covets and attempts to acquire for himself.

\section{In the Country of Last Things}

Paul Auster's 1987 novel In the Country of Last Things, depicting a post-apocalyptic American city in the throes of deep poverty, violence, and existential nihilism, is a distinctly different test of Auster's existing notions of postmodernism, post-structuralism, and metanarrative. The novel takes the form of an epistemological account by the novel's narrator, a young woman named Anna Blume, as she enters and explores the unnamed city in search of her brother William. While there, she experiences Auster's patented brand of abstracted, minimalist cultural exploration, Auster using her (more than any female character in The New York Trilogy) to explore the female condition in light of the decaying mythology of America and civilization.

Anna is characterized as a stranger in a strange land, presumably from a part of the country that has yet to fall in the way the titular 'country of last things' has. This lends her narration an intriguing level of abstraction and distance from the events around her, at least at first. In the opening pages, she writes anthropologically about the city and its eccentricities:

"These are the last things... When you live in the city, you learn to take nothing for granted. Close your eyes for a moment, turn around to look at something else, and the thing that was before you is suddenly gone. Nothing lasts, you see, not even the thoughts inside you" (Auster 1987, pp. 1-2).

For the first parts of the book, Anna simply describes the decaying world around her and the aggressive, violent, male-dominated world that she inhabits. Mankind has been broken up into sects of people dealing with the end of the world in various ways: the Smilers, who simply grin through the hazardous wind and rainstorms; the runners who train every day for a marathon in which they kill themselves by running until their hearts burst; those who are wealthy enough to attend wealthy hospice facilities where they can have lavish gatherings until they are euthanized, and so on. In all of this, Anna is disengaged from the world, simply recording it without becoming a part of it.

A Lacanian reading of Anna in the novel reveals a slowly changing and altering set of desires, needs and demands. At her core, Anna's ability to go "object-hunting" in the book is the purest distillation of the Lacanian impulse to desire and its relationship to the subjects of that desire. In crafting a complex arsenal of scavenging equipment, whose "apparatus" consists of herself, her shopping cart, and her "umbilical cord," Anna inherently creates a complex microcosm of the mechanisms of Lacanian desire; the subject is Anna, the cart (which can contain any object that stands in for the Other that can be desired), and the cord which connects the two (Auster 1987, p. 33). On a sheer surface level, Anna expresses her Lacanian desire by collecting these objects, which she both needs for survival and demands for a sense of connection to the old world - the place where 'last things' come from.

However, her Lacanian desires quickly become complicated by the regressive gender politics of the world she 
inhabits. First, she falls in with a couple, Isabel and Ferdinand; it is not long before Ferdinand attempts to rape Anna, who successfully fights him off. Isabel, it is implied, kills him the following night after deducing what he tried to do to Anna; Isabel dies of illness shortly afterward. After that, Anna enters a relationship with Sam, another young person chronicling the city's decline, falling into a traditional heteronormative relationship and becoming pregnant in a comparatively stable community of Jewish scholars hiding in the town's library.

Through a series of circumstances, Sam goes missing, Anna's baby miscarries, and she is rescued from certain death by the inhabitants of a homeless shelter run by the matron Victoria, with whom she starts another relationship. Here, Anna finds a sense of active (but exhausting) purpose in contributing to the shelter (Woburn House), even after Sam returns to her at the house. From here, Anna and the residents of Woburn House attempt (and fail) to build and maintain a sustainable community, the end of the novel implying she will find a way to escape the city.

In the progression of this journey, Anna's Lacanian desires for safety, security, hope, pleasure and love are all manifested by her continuing travel to and from these differing havens. Her relationships with Isabel, Sam and Victoria are, in some way, attempts to satisfy the Lacanian Other, endearing herself to whomever holds the social power within the small, sane communities she travels between.

\section{DISCUSSION}

Examining the myths and genres of American fiction writing in a postmodernist, poststructuralist way, Auster explores the inherent confusion and lack of purpose postmodernist thought lends its characters and readers. Along with the notion of personal mythology, Americans latch onto universal narratives specific to their culture in order to preserve a sense of normalcy (Han, 2014). Auster's works lean into this sense of unambiguous, causal storytelling, as noted by the protagonist of The Locked Room:

"To say that so and so was born here and went there, that he did this and did that, that he married this woman and had these children, that he lived, that he died, that he left behind these books or this battle or that bridge-none of that tells us very much. We all want to be told stories, and we listen to them in the same way we did when we were young" (Auster 1987 , p. 242-243).

These stories, then, reinforce social values, such as those that dictate gender norms like the typical roles of men and women. In presenting, then upending, these roles and values through deconstruction of typical narrative structure, Auster challenges the myths that created then, and the reader's ability to see through them to their problematic core.

Generally, Auster's works explore the kind of existential, philosophical separation many people experience from their own personal mythology; whether it is Quinn's dissociation from his identity as a detective writer/detective, Blue's increasingly abstracted relationship to 'the future Mrs. Blue,' or Anna's continual disruption of her own status quo, Auster's postmodern approach to the detective and dystopian novels leave their characters (especially female characters) with a precarious position within the personal mythology of the characters. Auster's positioning of women as emotional or thematic punching bags for the male protagonists - symbols of normalcy upon which the men of the books can project their own wants and needs without regard for the women's desires - paradoxically reinforces these norms, while still pointing out the destructive nature of this power relationship.

Auster's treatment of women in his works may seem unnecessarily cruel at first glance, but a closer examination of his commitment to subverting genre tropes by paradoxically pointing out their problematic elements elevates his female characters to highly symbolic status. In The New York Trilogy, all three protagonists are disillusioned male detectives to varying degrees, each of which have a woman they pine over in increasingly distanced ways. Quinn, in City of Glass, constantly pines over his deceased wife (and son), while also being attracted to the increasingly distant Virginia Stillman; Blue in Ghosts pines over the life he has/might have with Mrs. Blue, and The Locked Room's unnamed narrator covets not just Fanshawe's novel writing ability, but Fanshawe's wife as well.

The distinctly American concept of the nuclear family is firmly established in Auster's works as a fundamental component of each protagonist's ideal circumstances, and their inability to reach it is commensurate with the Austerian notion of "the disparate and often directly contradictory things that Americans buy - both materially and consciously - to confirm their success, assert their independence, and affirm their identity" (Heikemper-Yates 2014, p. 5). This contradiction is personified in the male characters' relationships with women, the wives and lovers of The New York Trilogy acting as objects to establish these ideals of success, independence and identity.

The most subversive female character in Auster's body of work, in this context, is Anna Blume from In the Country of Last Things. Unlike the female characters in The New York Trilogy, Anna represents Auster's sole attempt at creating a female point-of-view character; every event in the maddening, dystopian world of the post-apocalyptic future is viewed from her perspective (Neethi, 2014). As compared to the down on their luck, hapless and destitute detectives of The New York Trilogy, Anna is intrepid, resilient and practical, acting as "an alternative to the celebrated questing personal of the adventurous male hero" (Neethi 2014, p. 1).

To that end, the shifting goals and mannerisms of Anna throughout In the Country of Last Things cements her as a figure capable of tremendous change and vulnerability, being forced to adapt as her roles change within the interpersonal dynamics in which she finds herself. From individual anthropologist, to subjugated victim of attempted rape, to settled member of a heteronormative romantic relationship, to finally a proactive contributor to a larger community, Anna's journey allows Auster to explore the various archetypes of female involvement in dystopian society.

When viewed through a psychoanalytic lens, Anna's journey throughout In the Country of Last Things can be 
viewed as representative of the eternal pull between the $i d$ of the fallen society around Anna and the ever-present rationality and practicality of Anna's representative superego. From the beginning, Anna is a cold, impartial observer of the destitute society around her, which represents all the primitive impulses humans may be faced with in the wake of an unpredictable world without systems or order; the various factions of people killing themselves or others in various ways is distinctly alien to her, as it is to the reader. While Anna becomes more used to the chaos around her, the superego in her continually attempts to assert order in her surroundings, from her rejection of Ferdinand's sexual advances to her repeated search for a type of normative order outside of the violent chaos that exists in the city at large.

In this respect, Anna represents a comparative break from convention for Auster, as her mere presence as the protagonist eschews traditional male-dominated dystopian narratives of adventurous journeymen undergoing great quests to find their love. Instead, Anna is allowed to maintain a series of distinct goals which change according to her circumstances: at first she is looking for her brother William, then she settles into a life with Sam at the library, then she finds her role at Woburn House as a caretaker and fundamental part of the social fabric there. At no point, however, does she succumb to the social madness around her, instead searching for stability and normalcy outside the pandemonium of the city. This sets her apart psychologically and symbolically from most of Auster's protagonists, who are broken men in search of the normalcy that women (in their minds) provide them.

Despite her greater agency and centrality to Auster's narrative, she still acts as the mitigating force of sanity and pragmatism on the insane world around her, as does the rest of the women in Auster's works. Even within In the Country of Last Things, female characters like Isabel and Victoria take strong leadership roles and are forced to negotiate relationships and interactions with men. Isabel, for instance, is an immediate mitigating force on the destructive, caustic Ferdinand, who taunts Anna and eventually threatens her with rape: "Don't listen to him my angel... don't pay any attention to what that ogre says" (Auster 1987, p. 150). Isabel provides stability for Anna, encouraging her to dress in a more masculine fashion to avoid attention in the destructive world of the city. Victoria, meanwhile, takes care of a much larger family - the inhabitants of Woburn House - and exudes a sense of responsibility heretofore lacking in the instinctive world of the novel.

\section{CONCLUSION}

By evaluating the roles of female characters in Paul Auster's New York Trilogy and In the Country of Last Things from a post-structuralist, psychoanalytic perspective, Auster's body of work seems to allude to a gender-stratified understanding of American society and myth-building that is inherently male-centered. The women of The New York Trilogy, and Anna in In the Country of Last Things, act as the superego mitigating the primitive, instinctual impulses of the men and male-dominated forces around them. Just as Virginia, Quinn's wife, 'the future Mrs. Blue' and Sophie are symbolic representatives of the normative nuclear-family life dictated by American culture for The New York Trilogy's respective protagonists, Anna in Country is the calm, rational negotiator of a lawless, desperate and nihilistic dystopia of physical and sexual violence (which are explicitly male-coded).

In this respect, a Freudian/Lacanian reading of Auster's works further contributes the prevailing wisdom of most scholarly literature on Auster - that his works emphasize postmodernist, poststructuralist uncertainty of what actually constitutes the Real. In creating deconstructive works that question the norms, values and structures of detective and dystopian fiction, Auster breaks apart the shared American mythology of the nuclear family and community-based social order to question its value and maintenance without the mitigating force of women. In the absence of women's nurturing practicality and superego on the macro level, male-driven society would be torn apart by its own worst impulses - its $i d$.

\section{REFERENCES}

Alford, S.E. (1995). Spaced-out: signification and space in Paul Auster's "The New York trilogy." Contemporary Literature 36(4): 613-632.

Auster, P. (1985). City of glass. Faber \& Faber.

Auster, P. (1986). Ghosts. Faber \& Faber.

Auster, P. (1986). The locked room. Faber \& Faber.

Auster, P. (1987). In the country of last things. Viking Press.

Bulnes, C.H. (2012). Constructing the apocalyptic city in Paul Auster's 'In the country of last things'. Dissertation.

Dimovitz, S. A. (2006). Public personae and the private I: de-compositional ontology in Paul Auster's The New York Trilogy. MFS Modern Fiction Studies, 52(3), 613-633.

Freud, S. (1919). The uncanny. Penguin.

Freud, S. (1923). The ego and the id. W.W. Norton \& Company.

González, J. Á. (2011). 'Another History': Alternative Americas in Paul Auster's Fiction. Comparative American Studies An International Journal, 9(1), 21-34.

Han, T.D. (2014). Constructing, deconstructing, and reconstructing narrative in the wake of trauma with the fiction of Charles Brockden Brown and Paul Aster. Master's Theses. Paper 122. Dissertation.

Heitkemper-Yates, M. (2014). Conflict irresolution: post-postmodernism and the legacy of ironic subversion. Asian Conference on the Arts and Humanities, Kobe University, Japan.

Jones, G., \& Ells, K. (2011). Chaos And Complexity In Paul Auster's New York Trilogy. DQR Studies in Literature, 47(1), 627-639.

Jung, C.G. (1963). Memories, dreams, reflections Pantheon Books.

Krippner, S. (2009). The interior dialogue. Transitions 1: 4-7.

Lacan, J. (2007). Ecrits: the complete edition. W.W. Norton \& Company.

Lavender, W., \& Auster, P. (1993). The novel of critical en- 
gagement: Paul Auster's 'City of glass.' Contemporary Literature, 34(2), 219-239.

Loebbermann, D. (2012). Walking in the city: the homeless figure and the artist in late-twentieth century New York novels. In Pirates, Drifters, Fugitives: Figures of Mobility in the US and Beyond. Eds. Heike, P., Ganser, A., \& Gerund, K. Heidelberg.

Little, W.G. (2008). Nothing to go on: Paul Auster's City of glass. Contemporary Literature, 38(1), 133-164.

Neethi, A.V. (2014) The female quester in Paul Auster's in the country of last things. IU Journal of English Studies, 9(2). Ross, K. C. (2013). Developing A Method Of Literary Psychogeography In Postmodern Fictions Of Detection: Paul Auster's The New York Trilogy And Martin Amis's London Fields (Doctoral dissertation, Texas A\&M University-Commerce).

Smith, H. (2002). 'a Labyrinth Of Endless Steps': Fiction Making, Interactive Narrativity, And The Poetics Of Space In Paul Auster's" City Of Glass". Australasian Journal of American Studies, 21(2), 33-51. 